\title{
Case Report: Refractory hypotension during general anesthesia despite preoperative discontinuation of an angiotensin receptor blocker [version 1; peer review: 2
}

\section{approved]}

\author{
Raha Nabbi ${ }^{1}$, Harvey J Woehlck1, Matthias L Riess ${ }^{1-3}$ \\ ${ }^{1}$ Department of Anesthesiology, Medical College of Wisconsin, Milwaukee, WI, 53226, USA \\ 2Department of Physiology, Medical College of Wisconsin, Milwaukee, WI, 53226, USA \\ ${ }^{3}$ Clement J. Zablocki VA Medical Center, Milwaukee, WI, 53295, USA
}

\section{V1 First published: 14 Jan 2013, 2:12 \\ https://doi.org/10.12688/f1000research.2-12.v1}

Latest published: 14 Jan 2013, 2:12

https://doi.org/10.12688/f1000research.2-12.v1

\begin{abstract}
Due to their beneficial reduction in morbidity and mortality angiotensin receptor blockers (ARBs) have become increasingly popular to treat hypertension. However, similar to angiotensin converting enzyme inhibitors, they can lead to severe hypotension in conjunction with general anesthesia and thus have been recommended to be withheld in the morning of surgery. Here, we present a 51 year old female who developed severe refractory hypotension after induction of general anesthesia, although she had discontinued her medication 24 hours preoperatively as instructed. Therefore, halting ARBs for more than 24 hours before surgery may be necessary. Heightened awareness of this potential interaction and recognizing the need to treat with vasopressin is required when ARBinduced hypotension occurs.
\end{abstract}

\section{Keywords}

angiotensin receptor blocker, hypotension, anesthesia, vasopressin

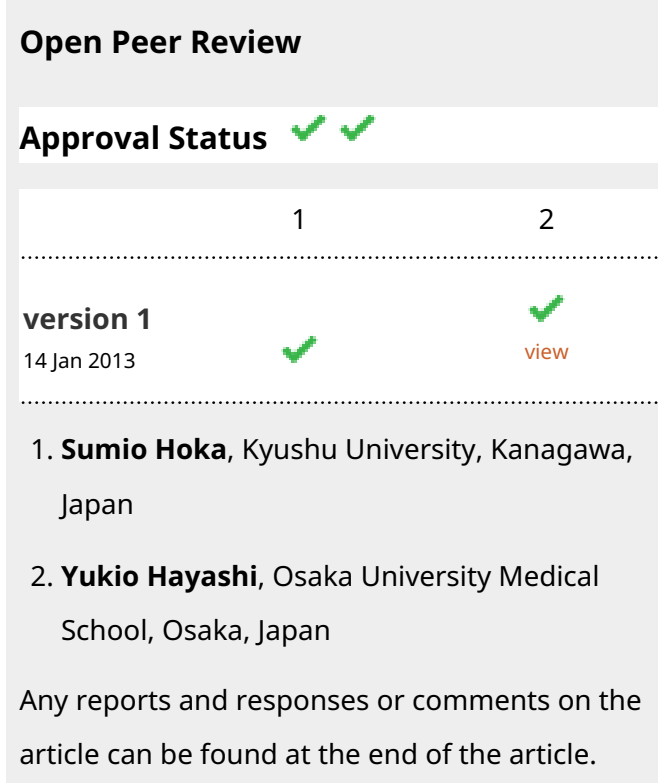


Corresponding author: Matthias L Riess (mriess@mcw.edu)

Competing interests: No competing interests were disclosed.

Grant information: Institutional support only (RN, HJW and MLR). No grants were involved in supporting this particular work. Unrelated research support for MLR through the Department of Veterans Affairs (CARA-026-10F) and NIH.

The funders had no role in study design, data collection and analysis, decision to publish, or preparation of the manuscript.

Copyright: ( 2013 Nabbi R et al. This is an open access article distributed under the terms of the Creative Commons Attribution License, which permits unrestricted use, distribution, and reproduction in any medium, provided the original work is properly cited. Data associated with the article are available under the terms of the Creative Commons Zero "No rights reserved" data waiver (CC0 1.0 Public domain dedication).

How to cite this article: Nabbi R, Woehlck HJ and Riess ML. Case Report: Refractory hypotension during general anesthesia despite preoperative discontinuation of an angiotensin receptor blocker [version 1; peer review: 2 approved] F1000Research $2013,2: 12$ https://doi.org/10.12688/f1000research.2-12.v1

First published: 14 Jan 2013, 2:12 https://doi.org/10.12688/f1000research.2-12.v1 


\section{Introduction}

Angiotensin II receptor blockers (ARBs) represent a newer class of effective and well tolerated antihypertensive agents ${ }^{1}$. Several clinical studies have indicated the beneficial effects of ARBs in hypertensive patients such as reduction of left ventricular hypertrophy, decrease in ventricular arrhythmias, and improved diastolic function ${ }^{1}$. Inhibitors of the renin-angiotensin system (RAS), either angiotensin converting enzyme (ACE) inhibitors or ARBs, mediate vasodilation and consequently decrease blood-pressure by different mechanisms ${ }^{1}$. ARBs specifically inhibit angiotensin II from binding to its receptor, the Angiotensin-1 ( $\mathrm{AT}_{1}$ ) receptor on vascular smooth muscle cells. This blockade results in increased angiotensin II and normal bradykinin plasma levels. ARBs were developed to overcome several deficiencies of ACE inhibitors, which, by comparison, lead to decreased angiotensin II, but increased bradykinin levels. Hence, the key advantage of ARBs over ACE inhibitors is their lack of adverse effects related to bradykinin potentiation. ARBs have been shown to reduce morbidity and mortality associated with hypertension, and therefore, it is not surprising that an increasing number of patients scheduled for surgery are chronically treated with $\mathrm{ARBs}^{2}$. However, RAS blockade increases the risk of severe hypotension during and after anesthetic induction. ACE-inhibitors are well known for inducing severe circulatory side effects during anesthesia, which led to the general recommendation to withhold the drug on the day of surgery ${ }^{3}$. Similarly, refractory hypotension has been described after induction of general anesthesia in patients chronically treated with ARBs who took their medication in the morning of surgery ${ }^{3}$. Here, we describe a case of severe hypotension under general anesthesia refractory to conventional treatment, despite preoperative discontinuation of an ARB for 24 hours.

\section{Case report}

A 51 year old female $(60 \mathrm{~kg})$ whose hypertension was well controlled with Diovan-HCT (valsartan/hydrochlorothiazide 160/12.5 $\mathrm{mg}$ ) was scheduled for a T2-10 posterior thoracic fusion. As instructed, she had last taken Diovan-HCT 24 hours prior to surgery. Her preoperative exam was unremarkable. Non-invasive blood pressure measurement, 5-lead ECG with ST segment analysis, heart rate, and pulseoximetry were continuously monitored. Her baseline vital signs were stable with a blood pressure of 136/94 $\mathrm{mmHg}$, heart rate of $86 \mathrm{bpm}$ and $\mathrm{SpO}_{2} 99 \%$ on room air. After induction of anesthesia with $150 \mathrm{mg}$ propofol, $100 \mathrm{mcg}$ fentanyl, and $60 \mathrm{mg}$ rocuronium and an uneventful intubation, her blood pressure decreased and remained $65-75 / 35-45 \mathrm{mmHg}$ for $45 \mathrm{~min}$ with a HR of 75-85 bpm despite rapid administration of $1500 \mathrm{cc}$ Lactate Ringer, repeated $100 \mathrm{mcg}$ phenylephrine boluses followed by a phenylephrine drip and repeated boluses of vasopressin (cumulative dose of 20 units within $25 \mathrm{~min}$ ). Sevoflurane for anesthesia maintenance was kept low at $0.8 \mathrm{Vol} \%$. Due to her refractory hypotension, the decision was made to postpone the patient's elective surgery and awaken her. Upon emergence, her blood pressure recovered to $115 / 65 \mathrm{mmHg}$ with a heart rate of $90 \mathrm{bpm}$, and she was extubated successfully after neuromuscular blocker reversal. The patient did not suffer any neurologic sequelae. Her ARB was withheld postoperatively and she was successfully anesthetized with the same drugs and operated on five days later without significant hypotension.

\section{Discussion}

Valsartan is a potent, highly selective antagonist of the angiotensin II at the $\mathrm{AT}_{1}$ receptor leading to vasodilatation and an anestheticinduced reduction in pre- and afterload. Vasodilation may also be afforded in part by upregulated angiotensin II activating $\mathrm{AT}_{2}$-receptors which causes vascular relaxation ${ }^{4}$ and reduces peripheral vascular resistance usually without a rise in heart rate. The efficacy, tolerability and safety of valsartan have been demonstrated in large-scale studies on patients with hypertension, heart failure and post-myocardial infarction ${ }^{5}$. Valsartan's mechanism of action is to displace angiotensin II from the $\mathrm{AT}_{1}$ receptor, thereby antagonizing $\mathrm{AT}_{1}$-induced vasoconstriction, aldosterone, catecholamine and arginine-vasopressin release, water intake, and hypertrophic responses. All of this results in a more efficient blockade of angiotensin II's cardiovascular effects and in fewer side effects than ACE inhibitors. In addition, most ARBs control blood pressure for $24 \mathrm{hrs}$ after a single dose.

ARBs are non-peptide compounds, and variations in molecular structure result in different binding affinities to their receptors and different pharmacokinetic profiles ${ }^{1}$. In comparison to other ARBs, valsartan's plasma elimination half life is of an intermediate duration $(5-10 \mathrm{hrs})^{6}$. It is eliminated mainly by non-renal routes. However, protein binding greatly affects its biological half life in the body. Valsartan is highly bound to plasma proteins (94-97\%), and these may act as a reservoir or depot from which the drug is slowly released and therefore exhibits a longer lasting effect on the vasculature ${ }^{6}$. As the unbound drug is metabolized and excreted from the body, some of the bound fraction is released in order to maintain equilibrium. In fact, our case demonstrates impressively that valsartan's biological half life is far outlived by its physiological effects in the human body and can consequently result in severe hypotension despite its prior discontinuation in cases when RAS activation is needed to maintain hemodynamic stability, as for instance during anesthesia. Indeed, during general anesthesia, maintenance of normotension becomes RAS-dependent ${ }^{7}$ and a pronounced anesthetic-induced hypotension may be prevented or at least attenuated by angiotensin II-mediated $\mathrm{AT}_{1}$ receptor activation. Conversely, by blocking RAS, systemic blood pressures can decrease markedly during general anesthesia ${ }^{4}$.

In addition, chronic $\mathrm{AT}_{1}$ blockade also reduces the vasoconstrictor response to $\alpha$ receptors activated by norepinephrine, which explains why ARB-induced hypotension can be so resistant to phenylephrine, ephedrine and norepinephrine ${ }^{2,8}$ as observed in our patient. The lack of response to repeated phenylephrine boluses and a continuous infusion, fluids and a decrease of the volatile anesthetic urgently required a different approach, and we administered vasopressin in repeated boluses. Clinical studies have shown significant vasoconstrictor effects of vasopressin and increased cardiac filling during echocardiographic measurements ${ }^{2}$. Vasopressin or its synthetic analogues can restore the sympathetic response and may be useful pressors in cases of refractory hypotension during anaphylaxis ${ }^{9}$ and septic shock ${ }^{10}$ as well as in patients on RAS inhibitors, although norepinephrine has been reported to have a more favorable effect on splanchnic perfusion and oxygen delivery ${ }^{11}$. 
We conclude that, similar to ACE inhibitors ${ }^{3}$, ARBs also need to be withheld for 24 hours prior to elective surgery, and - as our case illustrates - possibly longer to elude unnecessary morbidity and mortality associated with refractory hypotension following induction of general anesthesia in patients on chronic ARB treatment. Heightened awareness of this perilous interaction and recognizing the need to treat with an adequate dose of vasopressin or norepinephrine is required, when ARB-induced hypotension is encountered.

\section{Consent}

This case report is in accordance with institutional IRB-guidelines. We have been unable to obtain explicit written consent from the patient.

\section{Author contributions}

All authors were involved in the draft and revision of the manuscript and have agreed to its final content.

Competing interests

No competing interests were disclosed.

\section{Grant information}

Institutional support only (RN, HJW and MLR). No grants were involved in supporting this particular work. Unrelated research support for MLR through the Department of Veterans Affairs (CARA-026-10F) and NIH.

The funders had no role in study design, data collection and analysis, decision to publish, or preparation of the manuscript.
1. Israili $\mathrm{ZH}$ : Clinical pharmacokinetics of angiotensin II (AT $\left.{ }_{1}\right)$ receptor blockers in hypertension. J Hum Hypertens. 2000; 14(Suppl 1): S73-86. PubMed Abstract

2. Brabant SM, Eyraud D, Bertrand M, et al:: Refractory hypotension after induction of anesthesia in a patient chronically treated with angiotensin receptor antagonists. Anesth Analg. 1999; 89(4): 887-8. PubMed Abstract

3. Bertrand M, Godet G, Meersschaert K, et al.: Should the angiotensin II antagonists be discontinued before surgery? Anesth Analg. 2001; 92(1): 26-30. PubMed Abstract

4. Ryckwaert F, Colson $\mathrm{P}$, Andre $\mathrm{E}$, et al:: Haemodynamic effects of an angiotensinconverting enzyme inhibitor and angiotensin receptor antagonist during hypovolaemia in the anaesthetized pig. Br J Anaesth. 2002; 89(4): 599-604 PubMed Abstract | Publisher Full Text

5. Black HR, Bailey J, Zappe $D$, et al.: Valsartan: more than a decade of experience. Drugs. 2009; 69(17): 2393-414

PubMed Abstract | Publisher Full Text

6. Flesch G, Muller P, Lloyd P: Absolute bioavailability and pharmacokinetics of valsartan, an angiotensin II receptor antagonist, in man. Eur J Clin Pharmacol. 1997; 52(2): 115-20.

PubMed Abstract
7. Colson $\mathrm{P}$, Ryckwaert $\mathrm{F}$, Coriat $\mathrm{P}$ : Renin angiotensin system antagonists and anesthesia. Anesth Analg. 1999; 89(5): 1143-55.

PubMed Abstract

8. Licker M, Neidhart P, Lustenberger S, et al.: Long-term angiotensin-converting enzyme inhibitor treatment attenuates adrenergic responsiveness without altering hemodynamic control in patients undergoing cardiac surgery. Anesthesiology. 1996; 84(4): 789-800. PubMed Abstract

9. Hussain AM, Yousuf B, Khan MA, et al.: Vasopressin for the management of catecholamine-resistant anaphylactic shock. Singapore Med J. 2008; 49(9): e225-8. PubMed Abstract

10. Landry DW, Levin HR, Gallant EM, et al.: Vasopressin deficiency contributes to the vasodilation of septic shock. Circulation. 1997; 95(5): 1122-5. PubMed Abstract | Publisher Full Text

11. Morelli A, Tritapepe L, Rocco M, et al.: Terlipressin versus norepinephrine to counteract anesthesia-induced hypotension in patients treated with renin-angiotensin system inhibitors: effects on systemic and regional hemodynamics. Anesthesiology. 2005; 102(1): 12-9.

PubMed Abstract 


\section{Open Peer Review}

\section{Current Peer Review Status:}

\section{Version 1}

Reviewer Report 22 January 2013

https://doi.org/10.5256/f1000research.901.r717

(C) 2013 Hayashi Y. This is an open access peer review report distributed under the terms of the Creative Commons Attribution License, which permits unrestricted use, distribution, and reproduction in any medium, provided the original work is properly cited.

\section{Yukio Hayashi}

Department of Anesthesiology, Osaka University Medical School, Osaka, Japan

This report may give us several suggestions and it may be helpful to consider the anesthetic management of similar patients.

Competing Interests: No competing interests were disclosed.

I confirm that I have read this submission and believe that I have an appropriate level of expertise to confirm that it is of an acceptable scientific standard.

Reviewer Report 17 January 2013

https://doi.org/10.5256/f1000research.901.r708

(c) 2013 Hoka S. This is an open access peer review report distributed under the terms of the Creative Commons Attribution License, which permits unrestricted use, distribution, and reproduction in any medium, provided the original work is properly cited.

\section{Sumio Hoka}

Department of Anesthesiology and Critical Care Medicine, Kyushu University, Kanagawa, Japan

Competing Interests: No competing interests were disclosed.

I confirm that I have read this submission and believe that I have an appropriate level of expertise to confirm that it is of an acceptable scientific standard. 
The benefits of publishing with F1000Research:

- Your article is published within days, with no editorial bias

- You can publish traditional articles, null/negative results, case reports, data notes and more

- The peer review process is transparent and collaborative

- Your article is indexed in PubMed after passing peer review

- Dedicated customer support at every stage

For pre-submission enquiries, contact research@f1000.com 